\title{
Efektivitas Pemberdayaan Masyarakat Melalui Dana Desa di Kabupaten Lampung Barat
}

\author{
Zumaroh \\ Institut Agama Islam Negeri (IAIN) Metro, Indonesia \\ zumaroh@metrouniv.ac.id
}

\begin{abstract}
This research began with a community empowerment program launched through the Village Funds Budget. Community empowerment is the lowest priority in managing village funds after development and government. In fact, empowerment that currently does not reach $30 \%$ of the village funds budget can create a more independent community. However, until now the independence of the community has not been realized to its full potential. By using a socio-empirical research and program evaluation approach, it is expected that this research can obtain a real picture of the effectiveness of community empowerment through village funds in West Lampung. The community empowerment program launched by the government through the management of village funds in West Lampung is still not effective. This is caused by several factors, namely: the level of geographical difficulties of Pekon in the mountainous region, and the relatively low level of education of the community and Pekon apparatus. These causes make empowerment when viewed in terms of the programs offered are very good. However, the implementation is still not effective where the village funds management apparatus lacks the courage to develop the program on the grounds that there are no official technical guidelines from the regional government.
\end{abstract}

Keywords: Effectiveness; Community Empowerment; Village Funds

\begin{abstract}
Abstrak
Penelitian ini berawal dari program pemberdayaan masyarakat yang dicanangkan melalui Anggaran Dana Desa. Pemberdayaan masyarakat menjadi prioritas terendah pada pengelolaan dana desa setelah pembangunan dan pemerintahan. Sebenarnya, pemberdayaan yang saat ini tidak mencapai $30 \%$ dari anggaran dana desa dapat menciptakan kemandirian masyarakat yang masiv. Namun, hingga saat ini kemandirian masyarakat tersebut belum terwujud secara maksimal. Dengan menggunakan pendekatan penelitian sosio-empiris dan evaluasi program, diharapkan penelitian ini dapat memperoleh gambaran nyata tentang efektivitas pemberdayaan masyarakat melalui dana desa di Lampung Barat. Program pemberdayaan masyarakat yang dicanangkan pemerintah melalui pengelolaan dana desa di Lampung Barat masih belum efektif pelaksanaannya. Hal tersebut disebabkan oleh beberapa faktor penyebab, yaitu: tingkat kesulitan geografis Pekon yang berada pada wilayah pegunungan, serta tingkat pendidikan masyarakat dan aparatur Pekon yang masih relatif rendah. Faktor penyebab tersebut menjadikan pemberdayaan apabila dilihat dari segi program yang ditawarkan sudah sangat baik. Namun masih belum efektif pelaksanaannya dimana aparatur
\end{abstract}

FOKUS : Jurnal Kajian Keislaman dan Kemasyarakatan Vol. 4, No. 1, 2019

LPPM Institut Agama Islam Negeri (IAIN) Curup - Bengkulu

Available online: http://journal.staincurup.ac.id/index.php/JF

p-ISSN 2548-334X, e-ISSN 2548-3358 
pengelola dana desa kurang berani mengembangkan program dengan alasan belum ada petunjuk teknis resmi dari pemerintah daerah.

Kata Kunci: Efektivitas; Pemberdayaan Masyarakat; Dana Desa

\section{PENDAHULUAN}

Pembangunan merupakan suatu peningkatan kapasitas untuk mempengaruhi masa depan. Hal tersebut mempunyai beberapa implikasi tertentu yaitu pertama, memberikan perhatian terhadap kapasitas, yang diperlukan untuk mengembangkan kemampuan dan tenaga guna membuat perubahan tersebut. Kedua, pembangunan harus mencakup keadilan, perhatian yang berat sebelah kepada kelompok tertentu akan memecah belah masyarakat dan mengurangi kapasitasnya. Ketiga, penumbuhan kuasa dan wewenang dalam pengertian bahwa hanya jika masyarakat mempunyai kuasa dan wewenang tertentu maka mereka akan menerima manfaat pembangunan. Pembangunan berarti perhatian yang bersungguhsungguh terhadap saling ketergantungan di dunia serta perlunya menjamin bahwa masa depan dapat ditunjang kelangsungannya. Pembangunan tidak dapat didekati hanya dengan perubahan ekonomi, tapi secara umum pembangunan juga harus mampu menciptakan suatu kondisi yang dapat menjamin keadaan sosial masyarakat yang berkeadilan, kapasitas masyarakat yang dapat berkembang dengan pemberian wewenang dan kekuasaan serta lingkungan yang terjamin kesalingtergantungannya.

Kondisi ideal sebagaimana konsepsi di atas sangat sulit dicapai jika tidak didukung dan dikembangkan oleh berbagai pihak yang terlibat dalam proses pembangunan. Bagaimana pemerintah mampu memberikan perhatian terhadap kapasitas, yang diperlukan untuk mengembangkan kemampuan dan tenaga guna membuat perubahan atas masa depan masyarakat menjadi hal besar yang mempengaruhi perubahan itu sendiri. Saat pemerintah dan unsur pelaksana program pembangunan tidak mampu menciptakan keadilan dalam memeratakan pembangunan, maka masyarakat akan semakin terpecah belah. Masyarakat yang merasa diuntungkan pada posisi nyaman akan melenggang santai menikmati 
fasilitas pembangunan yang seharusnya dinikmati bersama pihak lain. Sebaliknya, masyarakat yang merasa tidak memperoleh keadilan dalam menikmati fasilitas pembangunan akan memiliki kecenderungan bersikap resisten terhadap program pembangunan yang dilaksanakan pemerintah.

Sikap resistensi masyarakat yang menganggap dirinya "lemah" terhadap berbagai program pembangunan menjadi problematika tersendiri apabila tidak diatasi. Sebenarnya hal tersebut dapat terkikis dengan sendirinya ketika tumbuh jiwa kemandirian dalam diri individu di masyarakat. Jiwa mandiri dapat ditumbuhkan melalui upaya pemberdayaan yang terus menerus. Masyarakat yang dalam dirinya telah tumbuh jiwa kemandirian sudah barang tentu tidak akan sepenuhnya tergantung kepada bantuan pemerintah. Masyarakat kemudian akan memaknai pembangunan sebagai wadah atau media untuk meningkatkan pemberdayaan diri dan lingkungannya.

Salah satu prasyarat bagi pengembangan pemberdayaan rakyat adalah perlunya kondisi keterbukaan yang lebih besar dalam masyarakat. Jika tidak ada keterbukaan, gerakan pemberdayaan masyarakat yang berkembang dapat berubah menjadi gerakan yang destruktif. Mengapa demikian? Karena saat keterbukaan tidak ada, gerakan pemberdayaan yang masiv dapat tampil sebagai reaksi terhadap kontrol. Akibatnya, ketegangan dapat timbul antara kebutuhan mengembangkan keberdayaan rakyat dan kecenderungan pemerintah untuk mempertahankan kontrol terhadap masyarakat. Masyarakat yang menilai pemerintah terlalu mendominasi kepentingan dalam program pemberdayaan masyarakat akan beranggapan bahwa hal tersebut dilakukan untuk mempertahankan kontrol terhadap masyarakat. Kontrol atas masyarakat dijadikan alat untuk mempertunjukkan kekuasaan. Masyarakat yang merasa tertindas akan menjadikan gerakan pemberdayaan tersebut sebagai alat melawan kontrol pemerintah. ${ }^{1}$ Dengan demikian, dibutuhkan program pemerintah yang memungkinkan melaksanakan pengembangan pemberdayaan tanpa

${ }^{1}$ Onny S. Prijono, A. M. W. Pranarka, dan Centre for Strategic and International Studies, Pemberdayaan: konsep, kebijakan, dan implementasi (Centre for Strategic and International Studies, 1996), hlm 106. 
potensi tindakan destruktif. Salah satu program pemerintah yang dapat mengakomodir kebutuhan tersebut adalah program pemberdayaan melalui dana desa.

Dana Desa adalah dana yang bersumber dari Anggaran Pendapatan dan Belanja Negara yang diperuntukkan bagi desa yang ditransfer melalui Anggaran Pendapatan dan Belanja Daerah kabupaten/kota dan digunakan untuk membiayai penyelenggaraan pemerintahan, pelaksanaan pembangunan, pembinaan kemasyarakatan, dan pemberdayaan masyarakat. ${ }^{2}$ Dalam pengelolaan dana desa, secara umum dana desa dialokasikan untuk pelaksanaan pembangunan infrastruktur dengan porsi anggaran terbesar dari dana desa. Selebihnya, dana desa dialokasikan untuk penyelenggaraan pemerintahan dan pemberdayaan masyarakat. Untuk pembangunan infrastruktur dan pemerintahan, para aparatur pengelola dana desa (dalam hal ini kepala Pekon $^{3}$ ) sudah memiliki acuan/pola yang tetap.

Pembangunan infrastruktur dan pengelolaan pemerintahan merupakan dua bidang yang telah melekat pada sistem operasional desa itu sendiri sesuai dengan ketentuan yang berlaku. Artinya, pengalokasian dana desa untuk melaksanakan penyelenggaraan pemerintahan dan pembangunan infrastruktur tinggal mengikuti petunjuk pelaksanaan dan petunjuk teknis yang diterbitkan pemerintah pusat melalui pemerintah daerah. Aparatur Pekon cukup mengalokasikan anggaran dana desa untuk kedua bidang tersebut sesuai dengan porsi yang telah direncanakan. Berbeda halnya dengan bidang pemberdayaan, antar wilayah di kabupaten Lampung Barat belum memiliki kesamaan persepsi tentang objek dan level pemberdayaan yang dilakukan. Hal tersebut disebabkan di antaranya

${ }^{2}$ Tim Visi Yustisia, Pedoman Resmi Petunjuk Pelaksanaan Dana Desa: Himpunan Peraturan Lengkap tentang Penganggaran, Pengalokasian, Penyaluran, Pelaporan, hingga Pemantauan dan Evaluasi Dana Desa (VisiMedia, 2016), 15; Tim Visi Yustisia, Undang-Undang Nomor 6 Tahun 2014 tentang Desa dan Peraturan Terkait (VisiMedia, 2015), hlm 18.

${ }^{3}$ Pekon merupakan istilah yang digunakan untuk menyebut nama "Desa atau Kampung" di beberapa wilayah di provinsi Lampung. Definisi rinci dapat dilihat pada Menembus Arus: Gerakan Mahasiswa Dan Perspektif Reformasi Dari Lampung (Tim Penyunting, 1998), 307 Pada Pekon, istilah Dana Desa disebut juga Dana Pekon . 
selain belum terdapat panduan dan program yang jelas dari Bupati tentang pemberdayaan yang ingin dikembangkan, batasan tentang apa dan bagaimana pemberdayaan itupun belum seragam antar aparatur Pekon, kecamatan, maupun kabupaten. Upaya nyata dari pengelolaan dana desa yang telah dilakukan adalah keharusan adanya Badan Usaha Milik Desa (BUMDes) yang mewakili pengembangan pemberdayaan ekonomi bagi masyarakat. BUMDes yang sudah tampak keberhasilannya, diantaranya BUMDes Pekon Tri Budi Syukur dan BUMDes Pekon Pura Jaya. Di Pekon Tugu Mulya dikembangkan BUMDes Koperasi Desa. Pemberdayaan masyarakat menjadi prioritas terendah pada pengelolaan dana desa setelah pembangunan dan pemerintahan. Jika pemberdayaan, yang saat ini tidak mencapai 30\% dari anggaran dana desa yang tersedia untuk dialokasikan dapat ditingkatkan cakupan dan besaran anggarannya, maka akan tercipta kemandirian masyarakat yang masiv. Kemandirian yang dimaksud di sini tidak hanya dari sektor ekonomi, tetapi meliputi berbagai bidang kehidupan lainnya. Namun, hingga saat ini kemandirian masyarakat tersebut belum terwujud. ${ }^{4}$

Permasalahan yang menjadi fokus kajian penelitian ini adalah masih kurangnya porsi alokasi dana desa untuk pemberdayaan masyarakat serta kebiasaan yang dilakukan aparatur pengelola dana desa yang masih mengikuti kebiasaan yang berkembang di berbagai Pekon di wilayah Lampung Barat. Pada umumnya di kabupaten Lampung Barat alokasi dana desa untuk program pemberdayaan masih digunakan untuk mengembangkan koperasi simpan pinjam dan pengembangan seni keislaman. Hanya beberapa Pekon saja yang melakukan pengembangan BUMDes dari dana desa untuk kegiatan selain koperasi dan pengembangan seni keislaman.

Dana desa adalah dana yang bersumber dari Anggaran Pendapatan dan Belanja Negara yang diperuntukkan bagi desa yang ditransfer melalui Anggaran Pendapatan dan Belanja Daerah kabupaten/kota dan digunakan untuk membiayai penyelenggaraan pemerintahan, pelaksanaan

\footnotetext{
${ }^{4} \mathrm{SH}$, Prioritas Pengalokasian Dana Desa di Kabupaten Lampung Barat, 29 Juli 2018.
} 
pembangunan, pembinaan kemasyarakatan, dan pemberdayaan masyarakat. Namun, dana desa diprioritaskan untuk membiayai pembangunan dan pemberdayaan masyarakat. Dana desa dialokasikan dari APBN berdasarkan Pasal 72 Ayat 1 Huruf b UU No 6/2014 tentang Desa. $^{5}$

Dasar Hukum pengelolaan dana desa antara lain: 1. Undang-Undang Nomor 6 tahun 2014 tentang Desa; 2. Peraturan Pemerintah Nomor 60 Tahun 2014 tentang Dana Desa yang bersumber dari Anggaran Pendapatan dan Belanja Negara sebagaimana diubah dengan Peraturan Pemerintah Nomor 22 Tahun 2015 tentang Perubahan Atas Peraturan Pemerintah Nomor 60 Tahun 2014 tentang Dana Desa yang Bersumber dari Anggaran Pendapatan dan Belanja Negara dan terakhir diubah dengan Peraturan Pemerintah Nomor 8 Tahun 2016 tentang Perubahan Kedua atas Peraturan Pemerintah Nomor 60 Tahun 2014 tentang Dana Desa yang Bersumber dari Anggaran Pendapatan dan Belanja Negara; 3. Peraturan Menteri Keuangan Nomor 49/PMK.07/2016 tentang Tata Cara Pengalokasian, Penyaluran, Penggunaan, Pemantauan, dan Evaluasi Dana Desa.

Dalam bidang pemberdayaan masyarakat, pemerintah memberikan beberapa ketentuan sebagai berikut:

1. Dana desa digunakan untuk membiayai program dan kegiatan bidang pemberdayaan masyarakat desa yang ditujukan untuk meningkatkan kapasitas dan kapabilitas masyarakat desa dengan mendayagunakan potensi dan sumber dayanya sendiri sehingga desa dapat menghidupi dirinya secara mandiri;

2. Kegiatan pemberdayaan masyarakat desa sebagaimana dimaksud pada ayat (1) diprioritaskan meliputi: a. peningkatan partisipasi masyarakat dalam proses perencanaan, pelaksanaan dan pengawasan pembangunan desa; b. pengembangan kapasitas di desa yang meliputi: pendidikan, pembelajaran, pelatihan, penyuluhan dan bimbingan teknis, dengan materi tentang pembangunan dan

\footnotetext{
${ }^{5}$ Yustisia, Undang-Undang Nomor 6 Tahun 2014 tentang Desa dan Peraturan Terkait, hlm 18.
} 
pemberdayaan masyarakat desa; c. pengembangan ketahanan masyarakat desa; d. pengelolaan dan pengembangan sistem informasi desa; e. dukungan pengelolaan kegiatan pelayanan sosial dasar di bidang pendidikan, kesehatan, pemberdayaan perempuan dan anak, serta pemberdayaan masyarakat marginal dan anggota masyarakat desa penyandang disabilitas; e. dukungan pengelolaan kegiatan pelestarian lingkungan hidup; f. dukungan kesiapsiagaan menghadapi bencana alam dan penanganannya; g. dukungan permodalan dan pengelolaan usaha ekonomi produktif yang dikelola oleh BUMDesa dan/atau BUMDesa Bersama; $h$. dukungan pengelolaan usaha ekonomi oleh kelompok masyarakat, koperasi dan/atau lembaga ekonomi masyarakat desa lainnya; i. pengembangan kerja sama antar desa dan kerja sama desa dengan pihak ketiga; j. bidang kegiatan pemberdayaan masyarakat desa lainnya yang sesuai dengan analisa kebutuhan desa dan ditetapkan dalam musyawarah;

3. Pengembangan kapasitas di desa sebagaimana dimaksud pada ayat (2) diswakelola oleh desa atau badan kerja sama antar-desa;

4. Swakelola oleh badan kerja sama antar-desa sebagaimana dimaksud pada ayat (3) dilaksanakan berdasarkan ketentuan dan mekanisme kerja sama antar-desa. ${ }^{6}$

Pemberdayaan merupakan terjemahan dari istilah asing dari bahasa Inggris, yakni dari kata empowerment, yang secara leksikal bermakna "penguatan". Secara teknis istilah pemberdayaan dapat disamakan atau setidaknya diserupakan dengan istilah pengembangan, dan istilah ini dalam batasan-batasan tertentu dapat dipertukarkan. Dalam pengertian lain, pemberdayaan atau pengembangan merupakan upaya memperluas horison pilihan manusia bagi masyarakat. Ini berarti masyarakat diberdayakan agar memiliki dan memilih sesuatu yang bermanfaat bagi dirinya. Dengan demikian, proses pengembangan dan pemberdayaan akan menyediakan sebuah ruang kepada masyarakat yang memiliki kualitas. Pada dasarnya Islam merupakan agama pemberdayaan. Dalam pandangan

${ }^{6}$ KUMPULAN PERATURAN PERUNDANG-UNDANGAN DESA DI INDONESIA (Marzha Tweedo, 2015), hlm 3. 
Islam pemberdayaan merupakan gerakan yang tanpa henti, yang sejalan dengan paradigma Islam sebagai agama perubahan, yang maknanya terkadang disamakan dengan pengembangan. Proses pemberdayaan masyarakat harus mengandung unsur partisipasi dan mobilisasi sosial (social mobilization). Hal paling mendasar yang harus dibangun dalam partisipasi dan mobilisasi sosial adalah membangun kesadaran akan pentingnya mereka sebagai agen perubahan sosial. ${ }^{7}$

Pemberdayaan secara substansial merupakan upaya pengembangan masyarakat sejalan dengan prinsip pengembangan masyarakat dalam Islam. Pemberdayaan masyarakat pada dasarnya merupakan suatu tindakan yang dilakukan untuk membuat masyarakat mampu memiliki dan memilih sesuatu yang bermanfaat bagi dirinya. Dalam konsep ini, masyarakat akan dibentuk menjadi pribadi yang berkualitas. Secara esensial, pemberdayaan yang dimaknai sama dengan pengembangan masyarakat Islam merupakan sistem tindakan nyata yang menawarkan alternatif model pemecahan masalah umat, baik itu masalah ekonomi, sosial, ekonomi dan lingkungan. Islam disebut juga sebagai agama perubahan, dan ini sejalan dengan esensi pemandirian yang melekat pada pemberdayaan. Pemberdayaan memiliki tujuan untuk memandirikan masyarakat melalui berbagai kegiatan yang mendorong daya kreatifitas, kemauan bekerja keras, serta secara bersama-sama melibatkan sesama masyarakat untuk mencapai kesejahteraan bersama. Saat masyarakat mandiri dalam bekerja dan berkarya, maka kesejahteraannya akan terus meningkat. Saat kesejahteraan meningkat, maka masyarakat akan terlepas dari rasa ketergantungan terhadap pihak lain, atau sikap mengandalkan bantuan.

Beberapa penelitian bertema pemberdayaan masyarakat melalui dana desa yang pernah dilakukan dan menjadi referensi bagi penelitian ini, di antaranya: Penelitian Kristina Korniti Kila dengan judul "Pengelolaan

\footnotetext{
${ }^{7}$ Nanih Machendrawaty dan Agus Ahmad Safei, Pengembangan masyarakat Islam: dari ideologi, strategi, sampai tradisi (Remaja Rosdakarya, 2001), 41-42; Firdaus, Pekanbaru Dari Metropolitan Menjadi Smartcity Menuju Masyarakat Madani (Elex Media Komputindo, 2018), hlm 93-94.
} 
Alokasi Dana Desa dalam Meningkatkan Pemberdayaan Masyarakat di Desa Miau Baru Kecamatan Kongbeng Kabupaten Kutai Timur" memperoleh hasil bahwa pengelolaan alokasi dana desa dalam meningkatkan pemberdayaan masyarakat di desa Miau Baru dan tidak melalui forum musyawarah (musrembang-desa) pada pelaksanaan anggaran/kegiatan yang tidak terealisasi sesuai dengan perencanaan yang telah ditetapkan sebelumnya. ${ }^{8}$

Penelitian lain berjudul "Pemberdayaan Masyarakat dalam Pemanfaatan Alokasi Dana (ADD) (Suatu Studi di Desa Bukumatiti Kecamatan Jailolo Kabupaten Halmahera Barat) yang dilakukan oleh Juliska Baura, Jantje Mandey, dan Femmy Tulusan. Penemuan penelitian ini adalah bahwa pemberdayaan masyarakat dalam pemanfaatan Alokasi Dana Desa (ADD) belum sesuai dengan asas pengelolaan keuangan dana desa yakni transparansi. Akuntabilitas dalam pemberdayaan masyarakat terhadap pemanfaatan ADD belum sesuai harapan masyarakat. Pemberdayaan masyarakat desa melalui pemanfaatan ADD tidak pernah melibatkan masyarakat dalam proses pengambilan keputusannya. ${ }^{9}$

Hasil penelitian yang dilakukan oleh Oktrian TSL, dkk menunjukkan bahwa pemanfaatan Anggaran Dana Desa untuk pemberdayaan masyarakat di desa Punagaya kabupaten Jeneponto masih belum optimal. Hal tersebut disebabkan oleh beberapa faktor yaitu ADD yang dialokasikan untuk pemberdayaan belum memadai, sering terlambatnya pengalokasian dana desa, serta kurangnya pengaruh aparatur desa terhadap pengembangan dan pengalokasian dana desa. Ketiga faktor tersebut menghambat pencapaian upaya peningkatan kreatifitas, kesejahteraan, dan lapangan kerja bagi masyarakat. ${ }^{10}$

8“EJournal Ilmu Administrasi Negara | PENGELOLAAN ALOKASI DANA DESA DALAM MENINGKATKAN PEMBERDAYAAN MASYARAKAT DI DESA MIAU BARU KECAMATAN KONGBENG KABUPATEN KUTAI TIMUR (Kristina Korniti Kila)," diakses 26 April 2019, https://ejournal.an.fisip-unmul.ac.id/site/?p=2357.

${ }^{9}$ JULISKA BAURA, JANTJE MANDEY, dan FEMMY TULUSAN, "Pemberdayaan Masyarakat Dalam Pemanfaatan Alokasi Dana (ADD) (Suatu Studi Di Desa Bukumatiti Kecamatan Jailolo Kabuapten Halmahera Barat)," t.t.

${ }^{10}$ Octrian Tsl, Mappamiring Mappamiring, dan Mappigau Samma, "IMPLEMENTASI PROGRAM ALOKASI DANA DESA (ADD) DALAM 
Riset yang dilaksanakan oleh Ahmad Sururi menjelaskan bahwa pemberdayaan diarahkan untuk meningkatkan akses hidup sejahtera bagi individu, keluarga, dan kelompok masyarakat terhadap sumber daya untuk melakukan proses produksi dan kesempatan berusaha. Pemberdayaan masyarakat melalui pembangunan infrastruktur pedesaan harus dilakukan berdasarkan prinsip-prinsip pemberdayaan. Adapun pembangunan infrastruktur pedesaan di kecamatan Wanasalam Banten justru belum melaksanakan prinsip pemberdayaan berupa analisis kerjasama partisipasi dan demokrasi. Hal ini disebabkan oleh kurangnya pemahaman masyarakat tentang pemberdayaan dan keterlibatannya dalam program pembangunan. Selain itu, kurangnya sosialisasi dari fasilitator masyarakat dan perangkat kelembagaan desa tentang kegiatan pembangunan dan pemberdayaan juga menjadi penghambat. ${ }^{11}$

Jika penelitian sebelumnya mengeksplorasi tentang upaya peningkatan pemberdayaan masyarakat melalui pengelolaan dana desa dan realisasi anggaran yang tidak sesuai dengan perencanaan, belum sesuai dengan asas pengelolaan keuangan desa, akuntabilitas yang tidak sesuai harapan masyarakat, serta rendahnya pelibatan masyarakat dalam proses pengambilan keputusan. Program pemberdayaan banyak tidak terlaksana dengan baik karena kurangnya alokasi dana desa. Kurang berhasilnya program pemberdayaan juga disebabkan karena kurangnya pemahaman masyarakat tentang keterlibatan dalam pemberdayaan serta kurangnya sosialisasi dari fasilitator masyarakat dan aparatur kelembagaan desa terkait program pemberdayaan itu sendiri. Maka penelitian ini mengkaji tentang efektivitas target program pemberdayaan masyarakat dapat dicapai melalui pengoptimalan pengelolaan dana desa. Selain ingin melihat bagaimana pola pengelolaan dana desa dan

PEMBERDAYAAN MASYARAKAT DI DESA PUNAGAYA KECAMATAN BANGKALA KABUPATEN JENEPONTO," Otoritas : Jurnal Ilmu Pemerintahan 3, no. 1 (14 April 2013), https://doi.org/10.26618/ojip.v3i1.63.

${ }^{11}$ Ahmad Sururi, "PEMBERDAYAAN MASYARAKAT MELALUI PROGRAM PEMBANGUNAN INFRASTRUKTUR PERDESAAN DALAM MENINGKATKAN KESEJAHTERAAN MASYARAKAT KECAMATAN WANASALAM KABUPATEN LEBAK," Sawala: Jurnal Administrasi Negara 3, no. 2 (13 Oktober 2017), https://doi.org/10.30656/sawala.v3i2.229. 
pemberdayaan masyarakat, penelitian ini juga ingin mengkaji apakah program pemberdayaan masyarakat sudah tepat sasaran dan sesuai dengan kebutuhan masyarakat di kabupaten Lampung Barat.

Terkait pemberdayaan masyarakat, Schumacer menyatakan bahwa "economic development can succed only if it is carried forward as a board popular "movement reconstruction" with the primary amphasis on the full utilization of the drive, anthusiasm, inteligence a labour power of every one". Strategi yang paling tepat dilakukan adalah dengan memberikan sarana kepada masyarakat agar dapat mengembangkan diri. ${ }^{12}$

Lebih lanjut Firdaus mengutip dari Elliot bahwa strategi pemberdayaan masyarakat dapat dilakukan dengan 3 (tiga) pendekatan, yaitu:

a. The Welfare Approach; pendekatan ini menekankan kepada pendekatan manusia bukan pada bagaimana memberdayakan manusia untuk menghadapi proses politik dan pemiskinan rakyat;

b. The Development Approach; tujuan pendekatan ini adalah untuk mengembangkan proyek pembangunan untuk meningkatkan kemampuan, kemandirian, keswadayaan masyarakat;

c. The Empowerment Approah, pendekatan ini melihat kemiskinan merupakan akibat dari proses politik dan berupaya memberdayakan atau melatih untuk mengatasi ketidakberdayaan masyarakat. ${ }^{13}$

Menurut Ginanjar Kartasasmita, memberdayakan masyarakat merupakan upaya memperkuat unsur-unsur keberdayaan untuk meningkatkan harkat dan martabat masyarakat dengan kekuatannya sendiri agar terlepas dari kemiskinan dan keterbelakangan. Artinya, pemberdayaan masyarakat merupakan upaya memampukan dan memandirikan masyarakat. Upaya memberdayakan masyarakat harus dilakukan melalui 3 jurusan. Pertama, menciptakan suasana yang memungkinkan potensi masyarakat berkembang (enabling). Kedua, memperkuat potensi atau daya yang dimiliki masyarakat (empowering).

\footnotetext{
${ }^{12}$ Dikutip dalam Firdaus, Pekanbaru Dari Metropolitan Menjadi Smartcity Menuju Masyarakat Madani, hlm 97-98.

${ }^{13}$ Firdaus, hlm 98.
} 
Ketiga, melindungi dari pihak yang menindas sehingga dapat mencegah kemungkinan masyarakat yang lemah semakin lemah. ${ }^{14}$

Permasalahan dalam penelitian ini dikaji dengan menggunakan pendekatan sosio-empiris dan evaluasi program. Pendekatan sosioempiris untuk mempelajari gejala atau pola pengelolaan dana desa dan pemberdayaan masyarakat di kabupaten Lampung Barat. Sedangkan pendekatan evaluasi program digunakan untuk mempelajari bagaimana efektivitas program pemberdayaan pemerintah yang dilaksanakan di kabupaten Lampung Barat.

\section{PEMBAHASAN}

Pemberdayaan belum memiliki porsi yang cukup ideal dalam penyaluran dana desa. Alasan yang dikemukakan adalah belum adanya juknis dari Pemerintah Daerah kabupaten dalam pengelolaan dana desa untuk pemberdayaan. Belum seragamnya pemahaman tentang penyaluran dana desa untuk pemberdayaan masyarakat menjadi alasan berikutnya yang membatasi para pengelola dana desa untuk dapat berinovasi dan mengembangkan pemberdayaan.

Penyaluran dana desa untuk pengembangan ekonomi dilaksanakan dalam rupa pengelolaan BUMDes. BUMDes di setiap Pekon berbedabeda bentuknya. Namun secara umum, BUMDes yang menjadi amanah pengembangan bidang ekonomi selalu dimaknai berupa koperasi. Bentuk koperasi BUMDes berbeda-beda, ada yang membentuk koperasi Simpan Pinjam, Kelompok Wanita Tani, atau UKM home industry dan waserda dengan produk olahan kopi. Aparatur pengelola dana desa hanya mengalokasikan di bawah $30 \%$ dari anggaran yang ada untuk pemberdayaan. ${ }^{15}$

\footnotetext{
${ }^{14}$ Ginandjar Kartasasmita, "Pemberdayaan Masyarakat Dalam Rangka Pengembangan Ekonomi Rakyat," Jurnal Bestari 0, no. 20 (19 April 2016): 31, http://ejournal.umm.ac.id/index.php/bestari/article/view/3154.

${ }^{15}$ AGS, Penyaluran Dana Desa Untuk Pengembangan Ekonomi, 22 Juli 2018.
} 
Terdapat 2 kecamatan yang dijadikan sebagai sampel wilayah penelitian untuk merepresentasikan daerah penelitian di kabupaten Lampung Barat. Data menunjukkan bahwa pola pengelolaan dana desa di kecamatan Sumber Jaya dan Kebun Tebu masih serupa. Penyaluran dana desa pada Pekon-Pekon yang ada di kedua kecamatan masih terpola untuk pelaksanaan pemerintahan dan pembangunan infrastruktur sebagai prioritas. Dengan kondisi letak geografis dan topografi yang cenderung sama, setiap Pekon yang ada di kedua kecamatan memiliki karakteristik pelayanan administrasi pemerintahan dan pembangunan infrastruktur yang sama. Sedangkan untuk pengembangan ekonomi (aspek pemberdayaan) masih terpaku pada pengadaan BUMDes. Porsi dana desa yang dialokasikan untuk BUMDes tidak lebih dari 30\%. Aparatur pengelola dana desa lebih nyaman mengalokasikan sebagaian besar dana desa untuk pelaksanaan pemerintahan dan pembangunan infrastruktur dengan alasan kedua bidang tersebut jelas petunjuk pelaksanaan dan petunjuk teknisnya dari pemerintah daerah. Sehingga peratin ${ }^{16}$ hanya tinggal mengimplementasikan saja.

Pengelola dana desa, dalam hal ini peratin mengalokasikan dana desa sesuai dengan ketentuan dari pemerintah daerah. Dana desa dialokasikan untuk pelaksanaan pemerintahan Pekon dalam pelayanan administrasi bagi masyarakat Pekon. Hampir semua Pekon yang ada di wilayah Lampung Barat mengalokasikan dana desa pada sektor pelayanan administrasi kelurahan ditunjang dengan sistem komputerisasi. Meskipun sumber daya manusia yang memiliki keahlian komputer terbatas, namun masih bisa mengelola pelayanan dengan menggunakan sarana komputer. Selain pelayanan administrasi dalam pelaksanaan pemerintahan, dana desa dialokasikan untuk membangunan infrastruktur penunjang kegiatan ekonomi dan sosial kemasyarakatan. ${ }^{17}$

Letak geografis dan topografi yang berada di pegunungan membuat hampir seluruh Pekon di Lampung Barat memiliki tantangan tersendiri dalam pembangunan infrastruktur. Pengelola dana desa harus jeli memilih

\footnotetext{
${ }^{17}$ AGS, Penyaluran Dana Desa Untuk Pengembangan Ekonomi.
} 
dan merencanakan pembangunan infrastruktur yang dibutuhkan masyarakat supaya dapat menopang aktifitas perekonomian masyarakat, khususnya di bidang pertanian. Penyaluran dana desa di kabupaten Lampung Barat masih diprioritaskan untuk pelaksanaan pemerintahan dan pembangunan infrastruktur. Pengelola dana desa menilai bahwa hal penting yang harus diberikan penguatan alokasi anggaran adalah pelayanan administrasi Pekon kepada masyarakat dan pembangunan sarana prasarana infrastruktur penunjang kegiatan sosial ekonomi kemasyarakatan. Pembangunan infrastruktur juga masih dilakukan untuk mengadakan sarana (fasilitas) layanan publik seperti balai Pekon, rumah ibadah, drainase, dan jalan. Sebagai daerah yang baru mekar, memang masih membutuhkan pengadaan banyak fasilitas fisik supaya roda perekonomian masyarakat dapat menggeliat lebih cepat. ${ }^{18}$

Skema dana desa yang digulirkan pemerintah berdasarkan undangundang tentang desa merupakan potensi yang sangat menjanjikan untuk memperbaiki dan meningkatkan taraf kesejahteraan masyarakat desa. Sebelum memperoleh bantuan dana desa, alasan ketertinggalan dari berbagai sentuhan kemajuan zaman dan modernisasi menjadi kambing hitam tidak bisa majunya masyarakat desa. Dengan adanya skema dana desa seharusnya tidak ada lagi kesenjangan yang terlalu lebar antara masyarakat desa dan masyarakat kota karena berbagai fasilitas yang dibutuhkan untuk menunjang kemajuan sudah diadakan secara bertahap melalui dana desa tersebut.

Dana desa telah diatur sedemikian rupa penyaluran dan pengelolaannya untuk menjadikan masyarakat menjadi lebih maju, lebih sejahtera, dan lebih mandiri. Secara tegas Undang-Undang mengatur bahwa dana desa digunakan untuk membiayai penyelenggaraan pemerintahan, pelaksanaan pembangunan, pembinaan kemasyarakatan, dan pemberdayaan masyarakat. Namun, dana desa diprioritaskan untuk membiayai pembangunan dan pemberdayaan masyarakat. ${ }^{19}$

\footnotetext{
${ }^{18}$ IDY, Pengalokasian Dana Desa di Lampung Barat, 29 Juli 2018.

${ }^{19}$ Peratin adalah nama lain dari Kepala Desa. Peratin merupakan istilah yang digunakan untuk menyebutkan kepala daerah pada tingkat Desa, dimana penyebutan Desa pada wilayah administratif kabupaten Lampung Barat menggunakan istilah Pekon.
} 
Dengan kejelasan aturan tentang pengelolaan dana desa tersebut, memudahkan desa untuk melakukan berbagai terobosan untuk semakin memajukan desanya. Berapa besaran dana desa yang diterima memang berbeda-beda antara satu desa dengan desa yang lain. Besaran Dana Desa setiap Desa sebagaimana dimaksud pada ayat (1) Peraturan Pemerintah Nomor 60 Tahun 2014 tentang Dana Desa yang Bersumber dari Anggaran Pendapatan dan Belanja Negara, dihitung berdasarkan jumlah penduduk desa, luas wilayah desa, angka kemiskinan Desa, dan tingkat kesulitan geografis. ${ }^{20}$ Tingkat kesulitan geografis sebagaimana dimaksud pada ayat (4) ditentukan oleh faktor yang meliputi: 1. ketersediaan pelayanan dasar; 2. kondisi infrastruktur; 3. transportasi; dan komunikasi desa ke kabupaten/kota. ${ }^{21}$

Hasil penelitian yang dilaksanakan menunjukkan bahwa hampir seluruh wilayah di Lampung Barat memiliki beberapa karakteristik yang sama terkait dengan letak geografis. Aturan yang dibuat pemerintah jelas bahwa besaran anggaran dana desa diantaranya mempertimbangkan faktor kesulitan geografis. Keempat faktor kesulitan geografis di atas ditemukan di wilayah Lampung Barat tersebut. Dengan kontur pegunungan, kedua kecamatan ini memiliki kesulitan tersendiri dalam mengakses pembangunan. Pemerintah daerah lampung Barat memiliki aturan tersendiri mengenai penetapan besaran bantuan dana desa yang akan dialokasikan pada setiap Pekon merujuk pada Peraturan Bupati Lampung Barat Nomor 24 tahun 2015. Dalam peraturan tersebut diatur secara detil tentang penetapan dana Pekon. Diantaranya adalah ketetapan mengenai tata cara penghitungan dana Pekon dan prioritas penggunaan dana Pekon dalam ketentuan perhitungan dana Pekon diatur bahwa: (a) dana Pekon setiap kabupaten telah ditetapkan pemerintah; (b) alokasi

Jika Desa dipimpin oleh seorang Kepala Desa, Pekon dipimpin oleh seorang Peratin. Tentang Pekon dapat dilihat pada Menembus Arus.

${ }^{20}$ KUMPULAN PERATURAN PERUNDANG-UNDANGAN DESA DI INDONESIA, 3.

${ }^{21}$ Secara rinci terdapat pula pada Yusran Isnaini SH.M.Hum, Memahami Desa: Tinjauan UU No. 6 Tahun 2014 Tentang Desa dan Peraturan Pelaksananya (Pradipta Pustaka Media, 2019). 
dasar yang merupakan alokasi yang dibagi secara merata kepada setiap Pekon sebesar 90\%; (c) alokasi dana dihitung berdasarkan formula yang terdiri dari jumlah penduduk, angka kemiskinan, luas wilayah dan tingkat kesulitan geografis setiap Pekon dengan bobot: 25\% untuk jumlah penduduk, 35\% untuk jumlah penduduk miskin, 10\% untuk luas wilayah, dan $30 \%$ untuk tingkat kesulitan geografis. Sedangkan prioritas penggunaan dana Pekon adalah untuk membiayai pembangunan dan pemberdayaan masyarakat yang meliputi: (a) pemenuhan kebutuhan dasar; (b) pembangunan sarana dan prasarana Pekon; (c) pengembangan potensi ekonomi lokal; dan (d) pemanfaatan sumber daya alam dan lingkungan secara berkelanjutan. ${ }^{22}$

Merujuk pada Peraturan Bupati di atas, memang alokasi dana desa untuk program pemberdayaan masyarakat maksimal hanya 35\% dari anggaran dana desa. Perhitungan alokasi 35\% dana desa dialokasikan untuk jumlah penduduk miskin adalah indikasi pengalokasian anggaran dana desa untuk pengentasan kemiskinan. Kemiskinan diatasi dengan program pemberdayaan masyarakat agar masyarakat menjadi lebih mandiri. Jika melihat secara parsial, memang bobot alokasi dana desa ini paling tinggi porsinya dibandingkan bidang yang lain. Namun secara keseluruhan, porsinya menjadi kecil. Maka wajar, ketika pemberdayaan yang dilakukan aparatur Pekon tidak dapat mencapai hasil maksimal. Terlebih ketika aparatur Pekon sangat membatasi keterlibatan masyarakat dalam program pemberdayaan tersebut.

Penyaluran dana desa untuk pengembangan ekonomi dilaksanakan dalam rupa pengelolaan BUMDes. BUMDes di setiap Pekon berbedabeda bentuknya. Namun secara umum, BUMDes yang menjadi amanah pengembangan bidang ekonomi selalu dimaknai berupa koperasi. Bentuk koperasi BUMDes berbeda-beda, ada yang membentuk koperasi simpan pinjam, kelompok wanita tani, atau UKM home industry dan waserda

${ }^{22}$ KUMPULAN PERATURAN PERUNDANG-UNDANGAN DESA DI INDONESIA Untuk di wilayah Lampung Barat ketentuan ini terdapat pada Peraturan Bupati Lampung Barat Nomor 24 Tahun 2015 tentang Tata Cara Pembagian dan Penetapan Rincian Dana Pekon Setiap Pekon yang Bersumber dari Anggaran Pendapatan dan Belanja Negara. 
dengan produk olahan kopi. Aparatur pengelola dana desa hanya mengalokasikan di bawah $30 \%$ dari anggaran yang ada untuk pemberdayaan. ${ }^{23}$

Paparan di atas menunjukkan bahwa pola pengelolaan dana desa di Lampung Barat masih serupa. Penyaluran dana desa pada Pekon-Pekon yang ada di wilayah tersebut masih terpola untuk pelaksanaan pemerintahan dan pembangunan infrastruktur sebagai prioritas. Dengan kondisi letak geografis dan topografi yang cenderung sama, setiap Pekon yang ada di kedua kecamatan memiliki karakteristik pelayanan administrasi pemerintahan dan pembangunan infrastruktur yang sama. Sedangkan untuk pengembangan ekonomi (aspek pemberdayaan) masih terpaku pada pengadaan BUMDes. Porsi dana desa yang dialokasikan untuk BUMDes tidak lebih dari 30\%. Aparatur pengelola dana desa lebih nyaman mengalokasikan sebagaian besar dana desa untuk pelaksanaan pemerintahan dan pembangunan infrastruktur dengan alasan kedua bidang tersebut jelas petunjuk pelaksanaan dan petunjuk teknisnya dari pemerintah daerah. Sehingga peratin hanya tinggal mengimplementasikan saja. Sedangkan untuk pemberdayaan belum ada keseragaman pola.

Sebenarnya BUMDes ini merupakan fasililas atau sarana yang dirancang untuk meningkatkan pemberdayaan masyarakat. Namun sempitnya pemahaman dan keengganan mengembangkan dengan alasan belum adanya kesamaan persepsi pada tingkat pengelola dana desa membuat BUMDes hanya seperti formalitas penyaluran anggaran dana desa sesuai amanah Undang-Undang.

Dengan adanya ketentuan bahwa dana desa harus ada yang dialokasikan untuk pemberdayaan, sebenarnya memberikan peluang lebih besar bagi masyarakat desa di kedua kecamatan tersebut menjadi lebih maju. Namun ternyata karena alasan tidak ada persepsi yang sama antara pengelola dana desa di tingkat Pekon dengan aparatur di tingkat kabupaten menjadikan faktor penyebab dibatasinya pengalokasian dana desa untuk tujuan pemberdayaan. Pengelola dana desa hanya berani

\footnotetext{
${ }^{23} \mathrm{SH}$, Prioritas Pengalokasian Dana Desa di Kabupaten Lampung Barat.
} 
menyalurkan dana desa tidak lebih dari 30\% untuk BUMDes yang mayoritas dipahami sebagai badan usaha koperasi. Tetapi tidak semua aparatur pengelola dana desa di Pekon membatasi hanya membuat koperasi sebagai wadah penyaluran dana desa bidang pemberdayaan. Dengan keberanian melakukan terobosan beberapa Pekon mampu mencapai kemajuan dengan program pemberdayaannya yang tidak dalam bentuk badan usaha koperasi. Memang tidak ditegaskan bahwa itu merupakan bagian dari alokasi dana desa. Namun, cara penempatan dana melalui BUMDes untuk menopang pembiayaan unit ekonomi yang lain memberikan peluang tersendiri bagi masyarakat untuk terlibat dan belajar mandiri dalam mengelola unit ekonomi.

Pada tataran ini tampak bahwa program pemberdayaan masyarakat yang dicanangkan pemerintah melalui pengelolaan dana desa masih belum efektif pelaksanaannya. Hal tersebut disebabkan oleh beberapa faktor penyebab yaitu: pertama, tingkat kesulitan geografis Pekon yang berada pada wilayah pegunungan. Pemberdayaan sebenarnya dapat dilakukan dengan merintis dan memperkuat lumbung ekonomi desa. Namun kendala letak geografis dapat menjadi penghambat pelaksanaan program pemberdayaan. Maka seyogyanya program pemberdayaan yang dibuat disesuaikan dengan potensi sumber daya alam dan ketersediaan infrastruktur yang dimiliki Pekon, serta daya jangkau (aksesibilitas) masyarakat pada lokasi pelaksanaan pemberdayaan apabila dilakukan terpusat pada satu atau beberapa daerah saja. Sulitnya transportasi dan komunikasi antara Pekon ke kabupaten juga merupakan kesulitan geografis yang menyebabkan tidak efektifnya realisasi program pemberdayaan masyarakat di wilayah Lampung Barat. Kedua, tingkat pendidikan masyarakat yang masih relatif rendah. Rendahnya tingkat pendidikan rata-rata masyarakat harus menjadi bahan pertimbangan untuk membuat program pemberdayaan yang memungkinkan dilaksanakan masyarakat. Rendahnya tingkat pendidikan juga membuat aparatur Pekon kurang memiliki keberanian untuk melakukan terobosan program pemberdayaan karena berpendapat harus ada aturannya terlebih dulu baru berani melaksanakan program. 
Ini berarti bahwa perlu ada petunjuk pelaksanaan dan petunjuk teknis yang jelas sebagai payung hukum bagi aparatur pengelola dana desa terkait dengan penyaluran dana desa bidang pemberdayaan. Apakah pemberdayaan masyarakat dapat dimaknai sama dengan pembinaan masyarakat perlu juga dibuatkan kerangka acuannya oleh pemerintah. Sehingga pengelola dana desa tidak akan merasa ragu mengalokasikan anggaran dana desa yang lebih besar untuk pemberdayaan. Dengan demikian program dana desa akan menjadi program pembangunan yang tepat sasaran sesuai kebutuhan masyarakat akan kemandirian. Tidak hanya sekedar fasilitas pembangunan fisik yang tidak akan bermanfaat maksimal tanpa sumber daya manusia yang handal dan mampu berdaya mandiri.

\section{PENUTUP}

Berdasarkan uraian di atas dapat disimpulkan bahwa program dana desa sudah sangat baik dalam konsep yang ditawarkan tentang pengalokasian pada bidang pemberdayaan. Namun, dalam pelaksanaan programnya masih belum efektif. Hal tersebut disebabkan oleh anggapan aparatur pengelola dana desa bahwa belum adanya petunjuk pelaksanaan dan petunjuk teknis yang jelas sebagai payung hukum bagi aparatur pengelola dana desa terkait dengan penyaluran dana desa bidang pemberdayaan, membuat pengelola dana desa ragu mengalokasikan anggaran selain untuk BUMDes Koperasi. Hanya beberapa Pekon yang berani melakukan terobosan membuat usaha pemberdayaan yang lebih tepat sasaran bagi masyarakat dengan mengkombinasikan skema BUMDes. Sehingga perlu diatur secara lebih jelas tentang penyaluran dana desa untuk pemberdayaan berdasarkan tingkat kesulitan geografis yang dimiliki setiap wilayah.

Berdasarkan kesimpulan penelitian di atas, maka disampaikan saran sebagai berikut: pertama, perlu adanya penyamaan persepsi tentang ruang lingkup pemberdayaan yang dapat didanai melalui skema dana desa. Kedua, perlu adanya petunjuk pelaksanaan dan petunjuk teknis tentang 
pengalokasian dana desa bidang pemberdayaan sebagaimana pada bidang pelaksanaan pemerintahan dan pembangunan infrastruktur.

Artikel ini disusun berdasarkan ketertarikan tentang Efektivitas Program Pemberdayaan Masyarakat Melalui Dana Desa di Kabupaten Lampung Barat. Artikel ini merupakan bagian dari Penelitian yang dilaksanakan oleh Penulis pada tahun 2018 dengan judul "Pemberdayaan Masyarakat Melalui Optimalisasi Pengelolaan Dana Desa di Kecamatan Sumber Jaya dan Kebun Tebu Lampung barat".

\section{DAFTAR PUSTAKA}

AGS. Penyaluran Dana Desa Untuk Pengembangan Ekonomi, 22 Juli 2018

Kristina Korniti Kila. E-Journal Ilmu Administrasi Negara | "PENGELOLAAN ALOKASI DANA DESA DALAM MENINGKATKAN PEMBERDAYAAN MASYARAKAT DI DESA MIAU BARU KECAMATAN KONGBENG KABUPATEN KUTAI TIMUR.” Diakses 26 April 2019. https://ejournal.an.fisip-unmul.ac.id/site/?p=2357

Firdaus. Pekanbaru Dari Metropolitan Menjadi Smartcity Menuju Masyarakat Madani. Elex Media Komputindo, 2018

IDY. Pengalokasian Dana Desa di Lampung Barat, 29 Juli 2018

JULISKA BAURA, JANTJE MANDEY, dan FEMMY TULUSAN. "Pemberdayaan Masyarakat Dalam Pemanfaatan Alokasi Dana (ADD) (Suatu Studi Di Desa Bukumatiti Kecamatan Jailolo Kabuapten Halmahera Barat)," t.t

Kartasasmita, Ginandjar. "Pemberdayaan Masyarakat Dalam Rangka Pengembangan Ekonomi Rakyat." Jurnal Bestari 0, no. 20 (19 April 2016).

http://ejournal.umm.ac.id/index.php/bestari/article/view/3154

KUMPULAN PERATURAN PERUNDANG-UNDANGAN DESA DI INDONESIA. Marzha Tweedo, 2015 
Machendrawaty, Nanih, dan Agus Ahmad Safei. Pengembangan masyarakat Islam: dari ideologi, strategi, sampai tradisi. Remaja Rosdakarya, 2001

Menembus Arus: Gerakan Mahasiswa Dan Perspektif Reformasi Dari Lampung. Tim Penyunting, 1998

Prijono, Onny S., A. M. W. Pranarka, dan Centre for Strategic and International Studies. Pemberdayaan: konsep, kebijakan, dan implementasi. Centre for Strategic and International Studies, 1996.

SH. Prioritas Pengalokasian Dana Desa di Kabupaten Lampung Barat, 29 Juli 2018

SH.M.Hum, Yusran Isnaini. Memahami Desa: Tinjauan UU No. 6 Tahun 2014 Tentang Desa dan Peraturan Pelaksananya. Pradipta Pustaka Media, 2019

Sururi, Ahmad. "PEMBERDAYAAN MASYARAKAT MELALUI PROGRAM PEMBANGUNAN INFRASTRUKTUR PERDESAAN DALAM MENINGKATKAN KESEJAHTERAAN MASYARAKAT KECAMATAN WANASALAM KABUPATEN LEBAK." Sawala: Jurnal Administrasi Negara 3, no. 2 (13 Oktober 2017). https://doi.org/10.30656/sawala.v3i2.229

Tsl, Octrian, Mappamiring Mappamiring, dan Mappigau Samma. "IMPLEMENTASI PROGRAM ALOKASI DANA DESA (ADD) DALAM PEMBERDAYAAN MASYARAKAT DI DESA PUNAGAYA KECAMATAN BANGKALA KABUPATEN JENEPONTO." Otoritas : Jurnal Ilmu Pemerintahan 3, no. 1 (14 April 2013). https://doi.org/10.26618/ojip.v3i1.63

Yustisia, Tim Visi. Pedoman Resmi Petunjuk Pelaksanaan Dana Desa: Himpunan Peraturan Lengkap tentang Penganggaran, Pengalokasian, Penyaluran, Pelaporan, hingga Pemantauan dan Evaluasi Dana Desa. VisiMedia, 2016

- Undang-Undang Nomor 6 Tahun 2014 tentang Desa dan Peraturan Terkait. VisiMedia, 2015 
46| Fokus : Jurnal Kajian Keislaman dan Kemasyarakatan, Vol 4, No. 01, Mei 2019 